\title{
Pengaruh Fungsionalitas dan Likeability Jalur LRT Terhadap Citra Kawasan Kelapa Gading
}

\author{
Eka Saputra ${ }^{1, *}$, Nurhikmah Budi Hartanti ${ }^{2}$ \\ ${ }^{1}$ Jurusan Arsitektur, Universitas Trisakti, Grogol, Jakarta Barat, Indonesia \\ eka152170007@std.trisakti.ac.id \\ ${ }^{2}$ Jurusan Arsitektur, Universitas Trisakti, Grogol, Jakarta Barat, Indonesia \\ nurhikmah@trisakti.ac.id
}

Received 23 August 2019, Revised 3 September 2019, Accepted 17 September 2019

\begin{abstract}
The development of the LRT pathway in the Kelapa Gading area is an alternative solution to increase movement and activities. The development of a new element will have an impact on changing the visual condition of an area, which in turn will affect the image formed in the community of the region. Therefore a study was conducted on the potential change in the image of the Kelapa Gading area with the LRT pathway as a new regional element. This research was conducted with a mix methods approach to determine the extent of potential changes that occur in the image of the Kelapa Gading area that has been formed with the presence of new elements, namely the LRT pathway. The focus of this research is on functional aspects and likeability of LRT path elements. The findings obtained are that the potential change in the image of the Kelapa Gading area is closely related to the functional aspects and likability of the LRT pathway, so that if the likability to the existence of a strong and functionally positive LRT pathway is positive for the community, then these elements can change the image of the Kelapa Gading area.
\end{abstract}

Keywords: Change image of the region, elements of LRT, likeability aspects, functional aspects

\begin{abstract}
Abstrak - Perkembangan jalur LRT di kawasan Kelapa Gading merupakan alternatif solusi terhadap pergerakan dan aktifitas yang semakin meningkat. Perkembangan suatu elemen baru akan berdampak pada perubahan kondisi visual suatu kawasan, yang selanjutnya akan mempengaruhi image yang terbentuk di masyarakat terhadap kawasan tersebut. Oleh karena itu dilakukan studi mengenai potensi perubahan citra kawasan Kelapa Gading dengan adanya jalur LRT sebagai elemen kawasan yang baru. Penelitian ini dilakukan dengan pendekatan mix methods untuk mengetahui sejauh mana potensi perubahan yang terjadi terhadap citra kawasan Kelapa Gading yang sudah terbentuk dengan kehadiran elemen baru yaitu jalur LRT. Fokus penelitian ini adalah pada aspek fungsional dan likeability terhadap elemen jalur LRT. Temuan yang diperoleh adalah bahwa potensi perubahan citra kawasan Kelapa Gading sangat terkait dengan aspek fungsional dan likability terhadap jalur LRT, sehingga apabila likability terhadap keberadaan jalur LRT kuat dan secara fungsional bernilai positif bagi masyarakat, maka elemen tersebut dapat merubah citra kawasan Kelapa Gading.

Kata Kunci: Perubahan citra kawasan, elemen baru LRT, aspek likeability, aspek fungsional
\end{abstract}

\section{PENDAHULUAN}

Kawasan Kelapa Gading dari sejak awal sampai saat ini terus berkembang pesat. Perkembangan kawasan perumahan dan komersial diikuti dengan peningkatan pergerakan dan aktifitas masyarakat. Tingginya aktifitas dan pergerakan masyarakat tentunya harus didukung dengan peningkatan aksesibilitas baik pembangunan sarana dan prasarana (Arifin, 2015). Pengembangan sarana baru hingga kini terus dikembangkan di kawasan Kelapa Gading yaitu pembangunan jalur LRT (Light Rapid Transit) tahap 1 sebagai salah satu solusi bagi aksesibilitas dan mobilitas masyarakat yang ramah lingkungan (Amar, 2009).

Perkembangan suatu kawasan dilihat dari perubahan maupun penambahan elemen-elemen fisik yang ada pada kawasan tersebut. Perkembangan elemen-elemen fisik akan mempengaruhi perubahan visual kawasan, sehingga seseorang dapat mempersepsikan atau bahkan mengingat kawasan tersebut melalui elemen-elemen yang ada di dalmnya (Amar, 2009). Penambahan maupun perubahan elemen-elemen perkotaan baik yang sudah ada maupun yang baru tentunya dapat memberikan persepsi yang berbeda atau gambaran visual yang baru bagi pengamatnya (Tjandra, 2015). Persepsi visual suatu kawasan berpengaruh dalam menentukan citra kawasan yang terbentuk (Nugroho, 2018). Selain itu, kondisi maupun persepsi visual masyarakat juga berpengaruh terhadap tingkat kejelasan serta kemudahan seseorang untuk mengingat dan mengenali bentuk dan kondisi kota tersebut (Aryanto,dkk, 2005). 
Berdasarkan pernyataan Mashita (2015), bahwa tolak ukur dalam pembentukan keunikan dan citra sebuah kota apabila dapat dilihat, diingat, serta dipersepsikan dengan mudah, maka kota tersebut dapat dikatakan sebagai kota yang baik. Semakin tinggi tingkat kejelasan sebuah kota khsususnya pada kolaborasi antara elemen-elemen pembentuknya, maka kota tersebut akan lebih mudah dikenali dan dipahami oleh masyarakat, karena memiliki tingkat imageability yang tinggi (Tohjiwa, 2011).

Kawasan kelapa Gading merupakan kawasan prumahan dan komersial yang terus mengalami perkembangan. Kawasan ini sudah memiliki citra yang selama ini sudah dikenal cukup kuat yaitu citra sebagai destinasi kuliner serta berbagai kondisi yang negatif/ distressing seperti macet, padat serta banjir (Rinaldi, 2005). Peningkatan perkembangan elemenelemen yang ada pada kawasan ini terus berlanjut meliputi penambahan elemen baru diantaranya adalah elemen LRT. Kehadiran elemen jalur LRT yang secara visual memiliki bentuk dan dimensi yang besar serta mendominasi view sebagian ruang jalan/ streetscape ruas Boulevard Raya (ditunjukan pada Gambar 2) secara tidak langsung akan merubah setting fisik dan visual kawasan Kelapa Gading. Pada gambar 1 menunjukan posisi keberadaan jalur layang LRT yang baru (garis titik-titik putih) yang membentang di sepanjang ruas jalur Boulevard Utama kawasan Kelapa Gading.

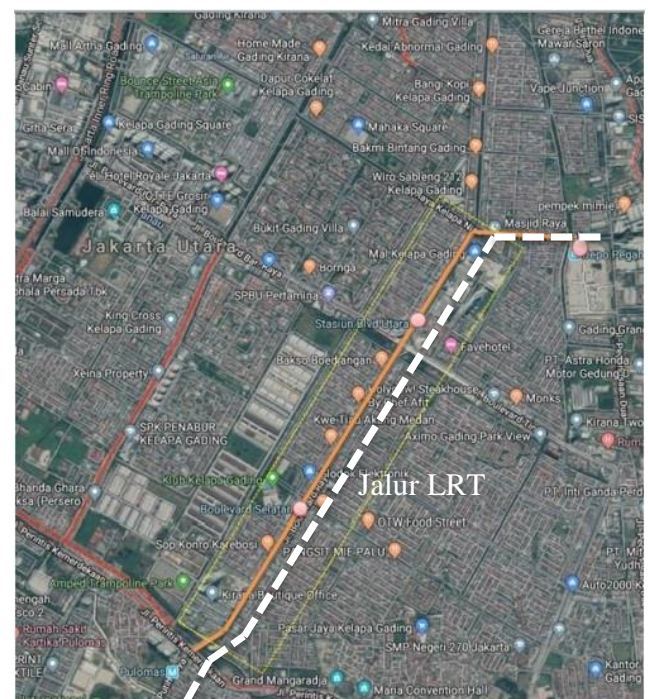

Gambar 1. Posisi keberadaan jalur LRT (garis titiktitik putih) di kawasan Kelapa Gading. (Sumber:

Modifikasi googlemaps, 2019)

Kehadiran jalur LRT sebagai elemen fisik kota yang baru tentunya akan mengubah bentuk fisik dan visual kawasan yang ada. Perubahan bentuk dan setting visual kawasan Kelapa Gading melalui kehadiran jalur LRT akan berpengaruh juga terhadap perubahan persepsi gambaran visual kawasan yang ada saat ini. Pada Gambar 2 merupakan perbandingan situasi dan kondisi visual streetscape di sepanjang ruas Boulevard Raya di kawasan Boulevard Raya
Kelapa Gading sebelum dan sesudah adanya jalur transportasi LRT.
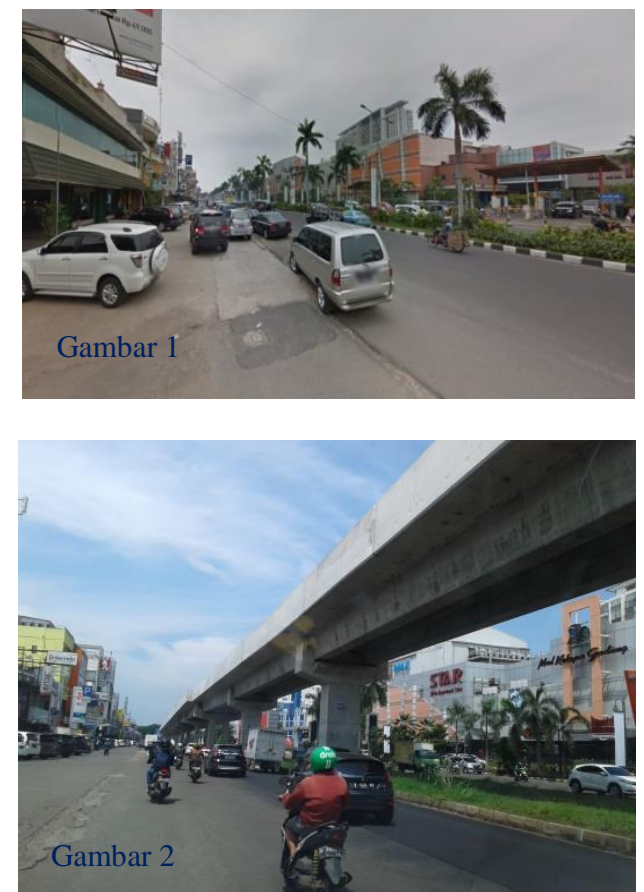

Gambar 2. Perubahan suasana dan kondisi visual kawasan sebelum (gambar 1) \& sesudah adanya jalur LRT (gambar 2) di kawasan Kelapa Gading. (Sumber: streetview (2013); foto pribadi (2019))

Penelitian ini dilakukan untuk mengetahui perubahan yang terjadi terhadap citra kawasan Kelapa Gading yang disebabkan keberdaan dari elemen baru berupa jalur LRT di Kawasan Kelapa Gading. Keberadaan jalur LRT yang baru di kawasan ini memiliki bentuk dan dimensi yang cukup besar dan menonjol, sehingga secara visual dapat merubah bentuk visual kawasan yang lama kelamaan akan membentuk citra baru bagi kawasan kelapa Gading melalui keberadaan jalur LRT tersebut. Citra kawasan Kelapa Gading yang sudah terbentuk selama ini berdasarkan beberapa literatur yang ada, merujuk kepada citra sebagai kawasan destinasi kuliner serta kawasan yang terkenal akan suasana yang negatif seperti macet yang disebakan oleh kepadatan lalu lintas serta banjir (Rinaldi, 2005). Sehingga kehadiran elemen baru dengan bentuk dan dimensinya yang cukup menonjol, serta secara visual mendominasi area streetscape ruang jalan dapat mengganggu pemnadangan terhadap view kawasan dan bangunan serta memberikan pengaruh negatif bagi citra kawasan Kelapa Gading secara keseluruhan.

Keberadaan elemen perkotaan baru yang berupa jalur LRT dengan bentuk dan dimensi yang cukup mendominasi area streetscape pada ruas jalan Boulevard di kawasan kelapa Gading tentunya dapat memberikan pengaruh baik positif maupun negatif terhadap potensi terjadinya perubahan visual kawasan kelapa Gading. Sehingga citra kawasan kelapa Gading akan turut berpotensi mengalami perubahan yang 
disebabkan oleh kehadiran elemen baru yang berupa jalur LRT tersebut. Selain itu, penelitian ini juga dilakukan untuk mengetahui pengaruh dari keberadaan jalur LRT terhadap perubahan citra kawasan serta keterkaitan antara aspek fungsional serta kesukaan masyarakat terhadap kehadiran elemen jalur LRT yang berpotensi merubah citra kawasan kelapa Gading.

Tujuan dari penelitian ini adalah untuk mengetahui pengaruh dari keberadaan fisik elemen baru yang berupa jalur LRT terhadap potensi perubahan citra positif maupun negatif bagi kawasan Kelapa Gading yang sudah terbentuk saat ini. Sedangkan manfaat dari penelitian ini adalah untuk mengetahui sejauh mana dan kaitannya antara fungsi dan kesukaan masyarakat terhadap objek LRT dengan perubahan image kawasan yang terjadi.

\section{Lingkup Penelitian}

Lingkup penelitian ini dilakukan pada area streetscape di sepanjang ruas jalan Boulevard Raya Kelapa Gading yang di tengah-tengahnya terdapat jalur LRT. Area streetscape pada lingkup penelitian ini dikarenakan jalan merupakan area yg paling banyak dialami orang ketika berada di suatu kawasan, sehingga streetscape atau tampilan visual ruang jalan akan sangat menentukan persepsi masyarakat terhadap kawasan (Hartanti, 2014). Fokus penelitian ini yaitu pada aspek dari makna fungsional dan kesukaan masyarakat akan keberadaan jalur LRT yang baru di kawasan Kelapa Gading serta pengaruhnya terhadap citra kawasan Kelapa Gading.

Beberapa penelitian yang pernah dilakukan sebelumnya oleh Aryanto, dkk (2005) yang meneliti tentang elemen potensial yang membentuk citra suatu kawasan. Selanjutnya adalah penelitian Tohjiwa (2011) yang mengidentifikasi elemen kota yang paling membentuk citra suatu kota berdasarkan kognisi pengamat. Selain itu penelitian Hartanti (2014) membahas tentang pembentukan identitas berdasarkan familiaritas terhadap karakter streetscape suatu kawasan, serta temuan lainnya. Pada penelitian ini mengeksplorasi mengenai perubahan citra kota yang disebabkan olah kehadiran elemen baru pada sebuah kota.

\section{Teknik Pengolahan dan Analisis}

Dilakukan dengan menggunakan teknik pengolahan data kuantitaif terkait penilaian masyarakat terhadap aspek-aspek likeability/ kesukaan masyarakat terhadap kehadiran jalur LRT yang berpengaruh terhadap image kawasan Kelapa Gading. Pengambilan data dilakukan melalui teknik survey kuesioner berbasis skala likert dengan rentang 1 - 5, untuk mendapatkan persepsi dan penilaian masyarakat terhadap aspek fungsionalitas dan kesukaan masyarakat melalui keberadaan jalur LRT. Tahapan analisis dilakukan dengan menggabungkan penilaian yang ada untuk dianalisis menggunakan sistem statistik untuk mendapatkan keterkaitan, kekuatan, serta arah hubungan antara kehadiran jalur LRT terhadap image kawasan kelapa Gading.

\section{STUDI LITERATUR}

\section{Citra Kawasan}

Suatu kota berdasarkan Lynch (1960), dapat dikatakan sebagai kota yang baik, apabila dinilai mampu memberikan gambaran atau kejelasan kepada seseorang ketika melihat dan mengamati kota tersebut. Citra sebuah kawasan/ kota yang terbentuk merupakan sebuah gambaran persepsi seseorang terhadap apa yang dilihat dan dirasakan pada kota tersebut. Sehingga sebuah kota akan dapat membuat seseorang mengingat dan mengenali bahkan mempersepsikannya dengan mudah karena memiliki tingkat kejelasan/ imagibilitas yang tinggi (Adrian \& Setioko, 2017).

Tingkatan kejelasan atau imagibilitas suatu kota, sehingga dapat dikenali atau diingat dengan mudah oleh orang yang melihatnya tercipta dari unsur-unsur yang tidak lain adalah kesatuan dari elemen-elemen fisik yang ada di dalam kota tersebut. Elemen-elemen yang merupakan objek pembentuk kota diantaranya adalah distrik/ kawasan, edges, landmark, path, serta nodes (Tjandra, 2015). Konfigurasi dari kelima elemen inilah yang akan menentukan tingkat kejelasan atau imageability suatu kota sehingga orang dapat mempersepsikan kondisi dan bentuk dari kota tersebut. Selain itu kelima elemen inilah yang juga akan membentuk kekhasan/ karakter yang membedakan antara suatukota dengan kota lainnya (Misavan, 2013).

Berdasarkan penelitian dari beberapa literature yang ada sebelumnya, telah dilakukan penelitian terkait dengan elemen-elemen dan faktor-faktor yang ada pada suatu kota yang digunakan serta yang memliki pengaruh yang kuat dalam menentukan dan membentuk citra bagi sebuah kota oleh Aryanto, dkk (2005), Tohjiwa (2011) dan Hartanti (2014).

\section{Aspek Perubahan Citra Kawasan}

Citra suatu kawasan perkotaan terbentuk berdasarkan imagibilitas atau tingkat kemudahan seseorang dalam menafsirkan atau bahkan mengenali serta mengingat kondisi kotanya. Citra sebuah kota terbentuk dari persepsi dan penilaian serta kesan dan kualitas yang diungkapkan oleh pengamat berdasarkan stuktur elemen-elemen fisik yang ada di dalam kota tersebut (Noviana, 2012). Aspek yang akan membentuk citra bagi sebuah kota adalah persepsi serta pemaknaan yang terjadi antara manusia/ pengamat kota terhadap wujud dari ruang kotanya serta elemen yang ada di dalamnya. Hal tersebut menimbulkan sebuah persepsi yang berasal dari ikatan atau hubungan signifikan antara seorang pengamat terhadap fungsionalitas dari elemen-elemen yang ada pada ruang kota tersebut (Wulaningrum, 2014).

Selain aspek pemaknaan akan kondisi yang tercipta di suatu kota, aspek lainnya yang sering 
digunakan untuk membentuk citra dari sebuah kota adalah aspek likeability. Menurut Nasar (1998), bahwa aspek likeability seorang pengamat diantaranya adalah terhadap keterbukaan suatu ruang kota, keteraturan kawasan perkotaan, serta signifikansi antar pengamat dengan elemen kota di dalamnya. Hal ini akan mempengaruhi citra yang tercipta pada suatu kawasan kota. Hal ini dikarenakan karena apabila seorang pengamat kota mengamati dan kemudian menyukai suatu tempat atau elemen yang ada pada kota tersebut, maka orang tersebut akan dengan mudah mengingat serta mengenali kota tersebut melalui kehadiran elemen fisiknya (Nugroho, Sabana \& Sanjaya, 2018).

\section{Kerangka Teori \& Kerangka Konsep}

Terbentuknya citra suatu kawasan dapat terbentuk melalui aspek pemaknaan terhadap fungsi dari elemen tersebut yang memberikan arti/ pengalaman khusus antara seorang pengamat dengan objek dan kotanya. Selain itu, aspek likeability juga dapat membentuk sebuah image bagi suatu kota, karena apabila seseorang menyukai apa yang ada pada kota tersebut, maka ia akan lebih mudah mengingat, mengenalinya dan dapat membentuk imageability terhadap kota tersebut. Kerangka konsep akan variabel yang digunakan dapat dilihat pada Tabel 1.

Tabel 1. Kerangka konsep

\begin{tabular}{ll}
\hline \multicolumn{1}{c}{ Image kawasan } & \multicolumn{1}{c}{ Elemen fisik kota } \\
\hline Pemkanaan Fungsional & Dimensi bentuk, \\
Likeability & wujud, serta posisi \\
Keteraturan & keberadaan jalur LRT \\
& di ruang kota Kelapa \\
& Gading. \\
\hline
\end{tabular}

\section{METODE PENELITIAN}

Pada penelitian ini menggunakan pendekatan gabungan atau mix methods (Yusuf, 2014). Pendekatan gabungan dilakukan melalui penggabungan data kuantitatif dan kualitatif dilakukan untuk mengetahui keterkaitan dan signifikansi dari keberadaan jalur LRT terhadap image yang saat ini tercipta oleh persepsi masyarakat. Instrumen analisis yang digunakan untuk mengetahui penilaian persepsi masyarakat terhadap keberadaan jalur LRT di Kelapa Gading dilakukan dengan menggunakan kuisioner penelitian serta analisis data dengan berbasis SPSS untuk mengetahui keterkaitan dan hubungan antar variabel terhadap keberadaan fisik jalur LRT. Penelitian ini dilakukan terhadap 150 responden dengan kombinasi antara warga dengan non warga Kelapa Gading. Tabel 2 merupakan definisi dari variabel yang dipakai dalam menentukan image kawasan Kelapa Gading terhadap kehadiran elemen jalur LRT.

Tabel 2. Definisi Operasional

\begin{tabular}{ll}
\hline \multicolumn{1}{c}{ Variabel } & \multicolumn{2}{c}{ Definisi Operasional } \\
\hline Pemaknaan & Hubungan yang tercipta antara \\
fungsional & seseorang pengamat terhadap
\end{tabular}

\begin{tabular}{ll}
\hline & suatu objek/ elemen kota \\
& berdasarkan sisi fungsionalitas \\
& dari elemen tersebut. \\
Likeability & $\begin{array}{l}\text { Pengalaman yang dirasakan oleh } \\
\text { seseorang pada suatu kota terkait }\end{array}$ \\
& dengan keterbukaan terhadap \\
& pandangan, pemeliharan dan \\
keteraturan pada suatu kawasan \\
Setting fisik \\
kawasan & $\begin{array}{l}\text { Bentuk fisik, dimensi, posisi dari } \\
\text { keberadaan jalur LRT yang } \\
\text { menempati ruang kota Kelapa } \\
\text { Gading. }\end{array}$ \\
\hline
\end{tabular}

\section{HASIL DAN PEMBAHASAN}

Terjadinya perubahan citra terhadap suatu kawasan perkotaan disebabkan oleh perubahan dan kehadiran elemen pembentuk kota yang baru pada suatu kawasan kota. Faktor pemaknaan fungsional serta Likeability suatu kota terhadap kehadiran elemen baru tersebut turut mempengaruhi terjadinya perubahan image bagi suatu kawasan kota. Selain itu keberadaan elemen baru juga berpengaruh terhadap persepsi visual seorang pengamat terhadap kondisi kotanya.

Variabel aspek yang digunakan dalam menentukan potensi perubahan citra pada kawasan Kelapa Gading diantaranya adalah aspek likeability dan pemaknaan fungsional akan keberadaan fisik jalur LRT pada kawasan ini. Aspek dari likeability/ kesukaan seseorang terhadap suatu elemen dan wujud suatu kota dilihat berdasarkan pemeliharaan, keterbukaan, keteraturan, keterpaduan, hingga kompatibilitas terhadap wujud fisik jalur LRT di ruang kota Kelapa Gading. Adapun aspek dari pemaknaan ditujukan pada fungsionalitas dari kehadiran elemen kota tersebut. Sehingga kedua variabel ini dapat menentukan potensi perubahan yang terjadi terhadap citra kawasan Kelapa Gading melalui kehadiran elemen baru yaitu jalur LRT.

Berdasarkan hasil rata-rata nilai persepsi penilaian pada tabel 3, citra kawasan Kelapa Gading perlahanlahan akan berubah di kemudian hari, melalui kemunculan elemen fisik yan baru yaitu jalur LRT. Keberadaan jalur LRT tersebut, berdasarkan hasil penilaian responden terhadap image kawasan melalui aspek fungsionalitas dan likeability terhadap keberadaan jalur LRT bagi kawasan Kelapa Gading mengarah ke arah yang positif (hasil rata-rata penilaian lebih besar dari 3). Hal ini terlihat dari persepsi rata-rata penilaian responden terhadap manfaat dan potensi keberadaan jalur LRT dalam merubah ciri khas kawasan kelapa Gading cukup tinggi.

Tabel 3. Rata-rata penilaian responden berdasarkan fungsional dan likeability jalur LRT

\begin{tabular}{|c|c|c|}
\hline Statement & Warga & Nonwarga \\
\hline $\begin{array}{l}\text { - Kehadiran LRT di Kelapa } \\
\text { Gading bermanfaat bagi } \\
\text { kemudahan \& kelancaran } \\
\text { aksesibilitas masyarakat. }\end{array}$ & 3,883 & 4,220 \\
\hline
\end{tabular}




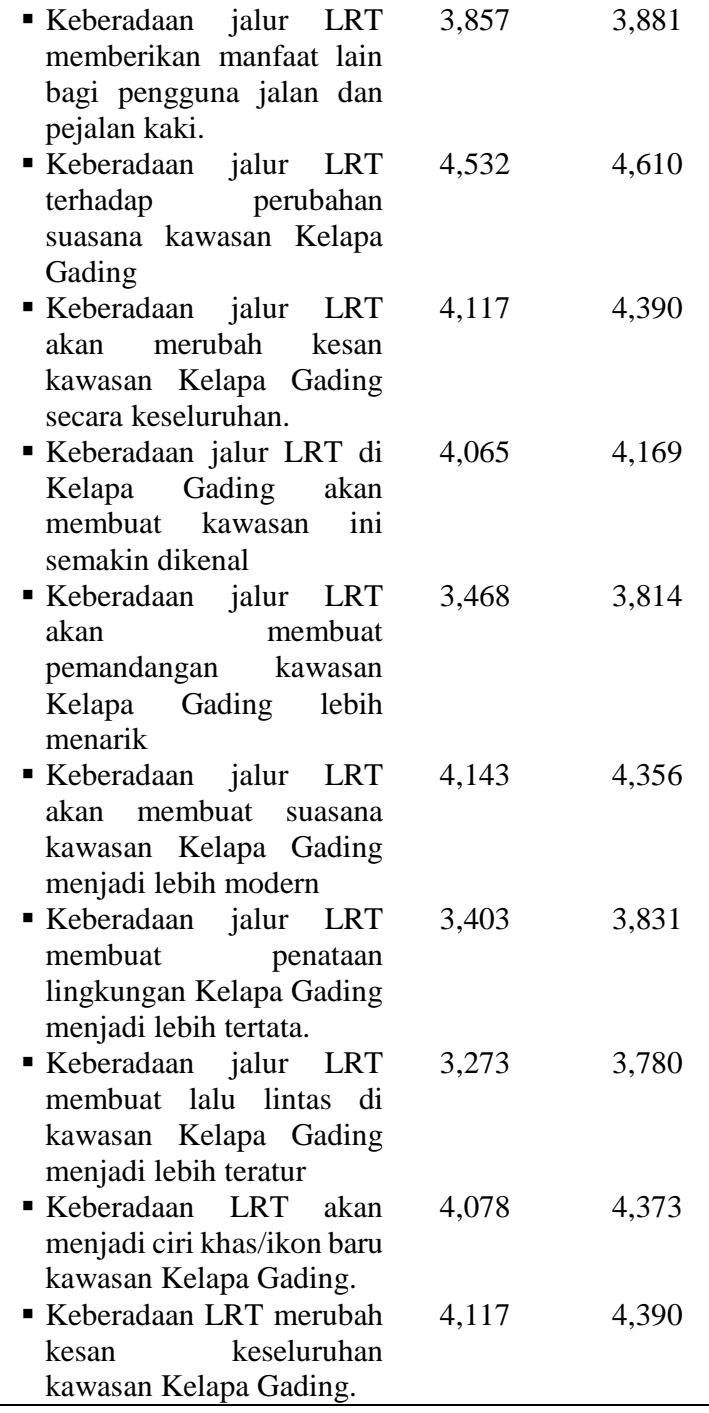

Pada tabel 3, hasil korelasi dapat dilihat bahwa nilai sig $0,00<0,05$, sehingga dapat disimpulkan bahwa terdapat hubungan antara aspek fungsionalitas LRT (semantic 4\&5) dan likeability akan kehadiran jalur LRT (likert 9-12) terhadap perubahan ciri khas dan kesan terhadap kawasan Kelapa Gading (semantic 6 , likert $7,8,13$ ). Selain itu, terdapat hubungan yang bersifat positif antar variabel aspek-aspek tersebut dikarenakan korelasinya bernilai positif. Itu berarti apabila ada perkembangan dan respon yang tinggi akan fungsional dan likeability dari keberadaan jalur LRT, maka semakin meningkat pula potensi perubahan kesan/ image yang tercipta bagi kawasan Kelapa Gading.

Tabel 4. Hasil korelasi antara aspek likeability dan fungsional keberadaan LRT terhadap potensi perubahan image kawasan Kelapa Gading

\begin{tabular}{cccc} 
& $\begin{array}{c}\text { Kelancaran } \\
\text { Aksesibilitas }\end{array}$ & $\begin{array}{c}\text { Manfaat } \\
\text { Pengguna }\end{array}$ & $\begin{array}{c}\text { Merubah } \\
\text { Suasana }\end{array}$ \\
\hline Ciri khas/ & 570 & 363 & 310 \\
ikon & 0,000 & 0,000 & 0,000 \\
Semakin & 438 & 327 & 263 \\
dikenal & 0,000 & 0,000 & 0,002 \\
& 600 & 577 & 223
\end{tabular}

\begin{tabular}{cccc} 
Semakin & 0,000 & 0,000 & 0,009 \\
menarik & & & \\
Semakin & 500 & 518 & 321 \\
modern & 0,000 & 0,000 & 0,000 \\
Semakin & 492 & 477 & 252 \\
tertata & 0,000 & 0,000 & 0,003 \\
Semakin & 440 & 459 & 350 \\
teratur & 0,000 & 0,000 & 0,000 \\
Merubah & 435 & 455 & 300 \\
kesan & 0,000 & 0,000 & 0,000 \\
\hline \multicolumn{4}{r}{ Keterangan: nilai korelasi (biru), nilai sig (hijau). } \\
\multicolumn{4}{l}{}
\end{tabular}

Berdasarkan hasil korelasi dari penilaian persepsi responden terhadap keberadaan jalur LRT, terdapat hubungan pengaruh positif yang signifikan antara fungsionalitas serta likeability msayarakat terhadap elemen baru yaitu LRT dengan potensi perubahan image bagi kawasan Kelapa Gading. Kondisi ini terlihat dari hasil perhitungan korelasi statistik yang menunjukan adanya pengaruh positif dari aspek fungsionalitas dan likeability dari keberadaan jalur LRT terhadap kawasan Kelapa Gading. Sehingga dapat ditarik analisis bahwa apabila semakin tingginya respon/ animo masyarakat terhadap terhadap fungsionalitas serta kesukaan masyarakat akan keberadaan jalur LRT yang baru di Kelapa Gading, tidak menutup kemungkinan akan berpengaruh dan berpotensi terhadap perubahan persepsi/pandangan bagi masyarakat terhadap kawasan Kelapa Gading.

\section{KESIMPULAN}

Kehadiran elemen baru pada kawasan Kelapa Gading yaitu jalur LRT mulai memliki pengaruh positif terhadap potensi perubahan image bagi kawasan Kelapa Gading secara keseluruhan. Potensi terhadap perubahan citra kawasan yang telah terbentuk sebelumnya akan dapat terjadi di kemudian hari apabila keberadaan jalur LRT yang merupakan elemen baru mendapatkan respon yang positif dan bermanfaat bagi masyarakat.

Aspek yang dilihat pada penelitian ini adalah aspek pemaknaan terhadap fungsionalitas dan likeability dari keberadaan objek LRT tersebut, yang di mana terdapat hubungan yang positif antara aspek tersebut terhadap citra kawasan Kelapa Gading. Berdasrakan hasil penelitian, bahwa kecenderungan responden mengarah kepada respon yang positif akan fungsionalitas dan likeability mereka terhadap keberadaan objek LRT pada kawasan ini.

Berdasarkan hasil penelitian dan korelasi yang dilakukan, terdapat hubungan positif yang saling terkait anatar aspek-aspek likeability dan fungsionalitas elemen fisik LRT terhadap citra kawasan Kelapa Gading yang sudah terbentuk sebelumnya. Kondisi ini akan menyebabkan terjadinya potensi perubahan citra bagi kawasan Kelapa Gading di kemudian hari apabila perkembangan dan respon masyarakat baik dari sisi fungsionalitas LRT maupun kesukaan orang terhadap objek LRT semakin meningkat dan positif. 


\section{REFERENSI}

Adrian, M. \& Setioko, B. (2017). Faktor-faktor yang mempengaruhi perubahan identitas kota di kawasan kota tua muara tebo kabupaten tebo provinsi jambi. Jurnal Pembangunan Wilayah \& Kota, 13(4), 459-472.

Amar, (2009). Identitas kota, fenomena dan permasalahannya. Jurnal Ruang, 1(1), 55-59.

Arifin, A. Julbidas, B. (2015). Studi konsep pengelolaan kawasan sebagai bagian terintegrasi dari proses pengembangan berkelanjutan sebagai business entity, studi kasus: kawasan Estat Sumarecon Kelapa Gading. Pusat Studi Metropolitan: Jakarta.

Aryanto, A., dkk. (2005). Kajian pembentuk citra kawasan Perumahan Taman Setiabudi Indah, Medan. Jurnal Arsitektur Atrium, 2(2),1-8.

Hartanti. N. B. (2014). Karakter Streetscape Sebagai Pembentuk Identitas Kota. Seminar Nasional Serap 3. Yogyakarta, 22-23 Agustus 2014.

Lynch, K. (1960). The image of the city. Massachusetts Institute of Tehcnology: United States of America.

Mashita, I, A. \& Heston, P, Y. (2015). Rekognisi bangunan dan citra kota. Seminar Nasional SCAN UAJY\#6. Volume 01.

Misavan, D. F. \& Gultom, B. J. (2013). Pengaruh pembaruan fasad bangunan terhadap karakter visual kawasan Jalan Tanjungpura, Pontianak. Jurnal Online Mahasiswa Arsitektur Universitas Tanjungpura, 1(1), 1-13.

Nasar, J. L. (1998). The evaluation image of the city. Sage Production: United States of America

Noviana, M. (2012). Kajian Elemen Pembentuk Citra Kawasan Jalan Kusuma Bangsa Samarinda. Jurnal Eksis Riset, 8(2), 2168 - 2357.

Nugroho, B. A. Sabana. S. \& Sanjaya. T. (2018). Identitas kota: pembangunan imaji kota melalui karya seni di ruang publik. Jurnal Rupa, 3(1), 44-54.

Rinaldi, J. M. (2005). Kawasan Kelapa Gading Jakarta. Urban Regional Development Institute. Lembaga Penerbit Urdi: Jakarta. 83

Tjandra, J. (2015.) Strategi Pencitraan Dalam Pengembangan Kota Baru. Pusat Studi Metropolitan: Untar Jakarta.

Tohjiwa, A. D. (2011). Citra Pusat Kota Depok Berdasarkan Kognisi Pengamat. Proceeding Pesat. Depok 18-19 Oktober 2011

Yusuf, M A. (2014). Metode Penelitian Kuantitatif, Kualitatif, Penelitian Gabungan. Prenada Media Group: Indonesia, Jakarta.

Wulaningrum, S. D. (2014). Elemen Elemen Pembentuk Kota Yang Berpengaruh Terhadap Citra Kota (Studi iKasus: Kota Lama Semarang). Jurnal Pengembangan Wilayah \&Kota, 10(2), 197204. 